\title{
DAKWAH DAN FENOMENA KEKERASAN DALAM RUMAH TANGGA
}

\author{
Siti Nurul Yaqinah \\ Fakultas Dakwah dan IImu Komunikasi UIN Mataram \\ e-mail: sitinurulyaqinah@yahoo.co.id
}

\begin{abstract}
The behavior of domestic violence is a tendency of behavior that is not in accordance with human nature and not in accordance with Islamic teachings. The causes of domestic violence can be classified into two factors, internal and external factors. Internal factors concerning the personality of the perpetrators of violence that makes it very easy to commit violence when faced with situations that cause anger or frustration. External factors are factors outside the abuser's self. For example economic difficulties, infidelity husband or wife, child and so forth. To minimize cases of domestic violence, the da'wah perpetrators promoted counselling of community-based da'wah, for example by promoting education on human rights and women's empowerment, and to socialize gender equality. Equally important is to build a mosquebased community economy and empower the work ethic of Muslims. This can be done through majlis taklim or other studies. Other efforts that can be done are preventive, educative, curative and rehabilitative
\end{abstract}

\section{Key words:}

Da'wah, Violence, Household 


\section{Abstrak}

Perilaku tindak kekerasan dalam rumah tangga merupakan suatu kecenderungan perilaku yang tidak sesuai dengan fitrah manusia sekaligus tidak sesuai dengan ajaran Islam. Penyebab terjadinya kekerasan dalam rumah tangga dapat digolongkan menjadi dua faktor, yaitu faktor internal dan eksternal. Faktor internal menyangkut kepribadian dari pelaku kekerasan yang menyebabkan ia mudah sekali melakukan tindak kekerasan bila menghadapi situasi yang menimbulkan kemarahan atau frustrasi. Faktor eksternal adalah faktor-faktor di luar diri si pelaku kekerasan. Misalnya kesulitan ekonomi, perselingkuhan suami atau istri, masalah anak, dan sebagainya. Untuk meminimalisir kasus-kasus kekerasan dalam rumah tangga, maka pelaku dakwah menggalakan penyuluhan masyarakat berbasis dakwah, misalnya dengan menggalakkan pendidikan mengenai HAM dan pemberdayaan perempuan, serta menyosialisasikan kesetaraan gender. Yang tidak kalah penting adalah membangun ekonomi masyarakat berbasis masjid dan memberdayakan etos kerja kaum Muslim. Hal ini bisa dilakukan melalui majelis taklim atau pengajian-pengajian lainnya. Upaya lain yang bisa dilakukan adalah tindakan preventif, edukatif, kuratif dan rehabilitative.

\section{Kata Kunci:}

Dakwah, Kekerasan, Rumah Tangga 


\section{A. Pendahuluan}

Kelvarga adalah unit sosial terkecil dalam masyarakat yang anggotanya terikat oleh adanya hubungan perkawinan (suami istri) serta hubungan darah (anak kandung) atau juga anak tiri atau anak pungut (adopsi). Aristoteles mengatakan bahwa posisi keluarga atas rumah tangga sangat sentral, yakni sebagai dasar pembinaan negara. ${ }^{52} \mathrm{Di}$ dalam keluargalah, seseorang pertama kali mendapat kesempatan menghayati penemuan-penemuan dengan sesama manusia, termasuk dalam memperoleh perlindungan pertama. Namun, kekerasan dalam rumah tangga (KDRT) menjadi wajah lain yang seringkali diterima sebagai hal yang "biasa", dan dipandang sebagai urusan internal keluarga yang bersangkutan. Bahkan banyak apologi diberikan bahwa 'kekerasan' itu merupakan bagian dari pendidikan dan pembinaan dalam rumah tangga. Hal ini merupakan ironi atas hakikat terbentuknya sebuah rumah tangga.

Mencermati berbagai peristiwa kekerasan dalam rumah tangga (KDRT) di Indonesia, cenderung yang menjadi korban adalah perempuan (istri). Realitas tersebut mengafirmasi bahwa kekerasan dalam rumah tangga berkaitan erat dengan persoalan gender, diskriminasi terhadap perempuan yang tidak pernah diangkat ke permukaan, serta diidentikan dengan sifat permasalahan ruang privat. Kekerasan yang disebabkan oleh bias gender ini disebut gender-related violence. $^{53}$ Di sebagian besar masyarakat, KDRT belum diterima sebagai suatu bentuk kejahatan. Oleh karena itu, banyak kasus KDRT diselesaikan secara kekeluargaan atau penangan hukum tidak tuntas. Padahal masyarakat internasional telah menciptakan standar hukum

\footnotetext{
${ }^{52}$ Kridawati Sadhana dalam Moerti Hadiati Soeroso, Kekerasan dalam Rumah Tangga dalam Perspektif Yuridis-Viktimologis (Jakarta: Sinar Grafika, 2012), viii.

${ }^{53}$ Ketidaksetaraan kekuatan yang ada dalam masyarakat menyebabkan munculnya bentuk kejahatan yang bisa dikategorikan sebagai kekerasan gender di antaranya pemerkosaan, pemukulan dan serangan fisik dalam ranah domestik, penyiksaan yang mengarah kepada organ alat kelamin, kekerasan dalam bentuk pelacuran, pornografi serta pelecehan seksual. Lihat Mansour Fakih, Analisis Gender dan Transformasi Sosial (Cet, III, Yogyakarta: Pustaka Pelajar, 2012), 17-20.
} 
yang efektif dan khusus memberikan perhatian pada KDRT dan Indonesia juga memiliki standar hukum yang efektif dan khusus mengenai KDRT, yaitu Undang-Undang Nomor 23 tahun 2004.

Mengingat korban kekerasan yang kebanyakan berjenis kelamin wanita itulah, para propagandis anti-KDRT beranggapan bahwa KDRT adalah masalah gender, yakni disebabkan adanya ketidak-adilan gender. Adanya subordinasi perempuan telah menempatkan mereka sebagai korban kekerasan oleh pria. Dan, ajaran agama (baca: Islam) dituduh melanggengkan budaya ini. Beberapa syariat Islam dicap sebagai upaya menyubordinasikan posisi wanita, sehingga menjadi pemicu bagi kaum pria untuk memperlakukan wanita semena-mena, yang berujung pada tindak kekerasan.

Kekerasan dalam rumah tangga sebenarnya bukan merupakan hal yang baru. Namun, selama ini selalu dirahasiakan atau ditutup-tutupi oleh keluarga, maupun oleh korban sendiri. Di samping itu, budaya masyarakat ikut berperan dalam hal ini. Kekerasan yang terjadi dalam rumah tangga mengandung sesuatu yang spesifik atau khusus. Kekhususan tersebut adalah terletak pada hubungan antara pelaku dan korban, yaitu hubungan kekeluargaan atau hubungan pekerjaan (majikan- pembantu rumah tangga). Selain itu, kekerasan dalam rumah tangga lebih spesifik, yaitu di dalam rumah, di mana pelaku dan korban bertempat tinggal.

Dalam konteks ini, maka dakwah hadir sebagai solusi karena boleh jadi kekerasan dalam rumah tangga terjadi karena kurangnya ilmu tentang tanggung jawab masing-masing pihak dalam keluarga, kondisi keimanan yang lemah sehingga amarah tidak terkendali, dan berbagai alasan lainnya yang menjadi pemicu terjadinya tindak kekerasan dalam rumah tangga. Selain itu, maraknya berbagai ketimpangan tersebut, disebabkan terkikisnya nilai-nilai agama dalam diri manusia. Oleh karena itu, tidaklah berlebihan jika dakwah merupakan bagian yang cukup penting bagi umat manusia saat ini. 


\section{B. Makna dan Bentuk Tindak Kekerasan dalam Rumah Tangga}

Pembicaraan tentang kekerasan dalam rumah tangga (KDRT) menjadi topik yang belakangan ini hangat dibicarakan. Media Massa, lembaga swadaya masyarakat khususnya yang mengusung isu gender, lembaga bantuan hukum dan lembaga peradilan begitu sibuk dengan topik yang sebenarnya sudah lama ini. Maraknya perilaku kekerasan dalam rumah tangga ini terjadi akibat fondasi rumah tangga tidak kokoh, boleh jadi hal ini disebabkan karena kurangnya ilmu tentang tanggung jawab masing-masing pihak dalam keluarga, kondisi keimanan yang lemah sehingga amarah tidak terkendali, dan berbagai bentuk alasan lainnya yang menjadi pemicu terjadinya tindak kekerasan tersebut.

Istilah kekerasan dalam rumah tangga dalam literature Barat umumnya digunakan secara bervariasi, misalnya "domestic violence", "family violence", "wife abuse". ${ }^{54}$ Namun Lisa Freedman mengemukakan bahwa kekerasan domestik tidak selalu menggambarkan situasi yang sebenarnya. Istilah seperti kekerasan dalam perkawinan dan kekerasan dalam keluarga yang menyamakan kekerasan terhadap istri atau suami, mengabaikan maksud dari sebagian besar tindak kekerasan semacam ini. Patut dipertimbangkan siapa yang paling berinisiatif di antara pasangan dalam rumah tangga untuk melakukan tindak kekerasan, termasuk juga adanya skala perbedaan dalam kekuatan fisik dan kemampuan bertikai antara suami istri, tingkat keseriusan dalam menggunakan kekuatan fisik. Apakah tindak kekerasan tersebut dimaksudkan untuk membela diri atau memang menyerang. ${ }^{55}$

Kekerasan dalam rumah tangga umumnya dilakukan oleh laki-laki terhadap perempuan, seperti kekerasan oleh suami terhadap istri.

\footnotetext{
${ }^{54}$ Allison Morris, Women, Crime and Criminal Justice, (USA: Basil Blackwell Inc, 1987), 181.

${ }^{55}$ Lisa Freedman, Wife Assault, dalam Connie Guberman et al. (ed) Safe Place, Violence Againts Women and Children (Tronto, Ontario: Womens Press, 11985), 41.
} 
Kekerasan rumah tangga kadang dikaitkan dengan istilah kekerasan terhadap pasangan. Kekerasan terhadap pasangan dapat terjadi antara pasangan yang menikah maupun yang tidak menikah. Lisa Freedman menggunakan istilah kekerasan dalam rumah tangga untuk bentuk kekerasan yang berhubungan antara suami istri, di mana salah satu di antaranya menjadi pelaku atau korban. ${ }^{56}$ Namun pada kenyataannya secara umum perempuan yang lebih cenderung menjadi korban (istri, anak maupun pasangan).

Berbagai pendapat, persepsi, dan definisi mengenai KDRT berkembang dalam masyarakat. Pada umumnya orang berpendapat bahwa KDRT adalah urusan intern keluarga dalam rumah tangga. Anggapan ini telah membudaya bertahun, berabad bahkan bermilenium lamanya, di kalangan masyarakat termasuk aparat penegak hukum. Jika seseorang (perempuan atau anak) disenggol di jalanan umum dan ia minta tolong, maka masyarakat termasuk aparat kepolisian akan segera menolong dia. Namun jika seseorang dipukuli sampai babak belur di dalam rumahnya, walaupun ia sudah berteriak minta tolong, orang segan menolong karena tidak mau mencampuri urusan rumah tangga orang lain. Berbagai kasus berakibat fatal dari kekerasan orang tua terhadap anaknya, suami terhadap istri, majikan terhadap pembantu rumah tangga, terkuak dalam media Massa. Masyarakat membantu dan aparat polisi bertindak setelah akibat kekerasan sudah fatal, korbannya sudah cacat bahkan meninggal dunia.

Menurut Undang-undang KDRT, KDRT adalah setiap perbuatan terhadap seseorang, terutama perempuan, yang berakibat timbulnya kesengsaraan atau penderitaan secara fisik, seksual, psikologis, dan atau penelantaran rumah tangga termasuk ancaman untuk melakukan perbuatan, pemaksaan, atau perampasan kemerdekaan secara melawan hukum dalam lingkup rumah tangga (pasal 1 butir 1).

Lingkup rumah tangga dalam undang-undang ini meliputi: pertama, suami, istri dan anak, kedua, orang-orang yang mempunyai hubungan

\footnotetext{
${ }^{56}$ Lisa Freedman, Wife Assault, dalam Connie Guberman et al. (ed) Safe Place, Violence Againts Women and Children, 44.
} 
keluarga dengan orang sebagaimana dimaksud dalam item pertama karena hubungan darah, perkawinan, persusuan, pengasuhan dan perwalian, yang menetap dalam rumah tangga; dan/atau, ketiga, orang yang bekeria membantu rumah tangga dan menetap dalam rumah tangga, dipandang sebagai anggota keluarga dalam jangka waktu selama berada dalam rumah tangga yang bersangkutan. ${ }^{57}$

Dengan demikian kekerasan dalam rumah tangga bisa menimpa siapa saja termasuk ibu, bapak, suami, istri, anak atau pembantu rumah tangga. Namun secara umum pengertian KDRT lebih dipersempit artinya sebagai penganiayaan oleh suami terhadap istri. Hal ini bisa dimengerti karena kebanyakan korban KDRT adalah istri. Sudah barang tentu pelakunya adalah suami. Rumah tangga bukan tempat (ajang) melampiaskan emosional suami terhadap istri. Tetapi rumah tangga adalah tempat yang aman. Tempat dimana kehangatan selalu bersemi, di dalamnya terdapat pasangan suami-istri yang saling mencintai.

Dari berbagai kasus yang pernah terjadi di Indonesia, bentuk-bentuk KDRT dapat dikelompokkan menjadi berikut ini. ${ }^{58}$

\section{a. Kekerasan Fisik}

Kekerasan Fisik merupakan bentuk kekerasan, di mana korban mengalami penderitaan secara fisik baik dalam bentuk yang ringan maupun berat. Kekerasan fisik dalam bentuk yang ringan misalnya mencubit, menjambak, memukul dengan pukulan yang tidak menyebabkan cidera dan sejenisnya. Kekerasan fisik kategori berat misalnya memukul hingga cidera, menganiaya, melukai, membunuh dan sejenisnya. Kekerasan fisik dengan bekas yang dapat dilihat dengan kasat mata biasanya mudah diproses secara hukum karena terdapat bukti materil yang dapat digunakan sebagai alasan.

b. Kekerasan Seksual

\footnotetext{
${ }^{57}$ UU RI Tentang Penghapusan Kekerasan dalam Rumah Tangga Nomor 23 Tahun 2004

${ }^{58}$ Aroma Elmina Martha, Hukum KDRT Kekerasan dalam Rumah Tangga (Yogyakarta: Aswaja Pressindo, 2015), 5-8.
} 
Kekerasan seksual dapat berbentuk pelecehan seksual seperti ucapan, symbol dan sikap yang mengarah kepada porno, perbuatan cabul, perkosaan dan sejenisnya. Kekerasan seksual juga meliputi eksploitasi seksual yang disertai hubungan seksual dengan yang lain tanpa keinginan perempuan. Termasuk hubungan seksual suami istri yang dilakukan tanpa persetujuan, perkosaan, pencabulan, control seksual akan hak untuk menghasilkan keturunan, dan berbagai bentuk manipulasi seksual yang dilakukan oleh pelaku dengan memaksa istri untuk melakukan hubungan seksual dengan cara-cara yang tidak wajar atau bahkan tidak memenuhi kebutuhan seksual istri.

c. Kekerasan Psikis

Kekerasan psikis adalah suatu tindakan penyiksaan secara verbal (menghina, berkata kasar dan kotor), sikap atau tindakan yang tidak menyenangkan yang mengakibatkan menurunnya rasa percaya diri, meningkatkan rasa takut, hilangnya kemampuan untuk bertindak dan tidak berdaya.

d. Kekerasan Ekonomi

Bentuk kekerasan ekonomi pada umumnya tidak menjalankan tanggung jawabnya dalam memberikan nafkah dan hak-hak ekonomi lainnya terhadap istri, anak, atau anggota keluarga lainnya dalam lingkup rumah tangga. Kekerasan ekonomi juga merupakan suatu tindakan yang membatasi istri untuk bekerja di dalam ataupun di luar rumah untuk menghasilkan uang dan barang, termasuk membiarkan istri yang bekerja untuk diekploitasi, sementara si suami tidak memenuhi kebutuhan ekonomi keluarga.

Sebagian suami juga tidak memberikan gajinya pada istri karena istrinya berpenghasilan, suami menyembunyikan gajinya, mengambil harta istri, tidak memberikan vang belanja yang mencukupi, atau tidak memberi uang belanja sama sekali, menuntut istri memperoleh penghasilan lebih, dan tidak mengijinkan istri untuk meningkatkan karirnya. 


\section{Faktor Pendorong Tindak Kekerasan dalam Rumah Tangga}

Penyebab terjadinya kekerasan dalam rumah tangga dapat digolongkan menjadi dua faktor, yaitu faktor internal dan eksternal. ${ }^{59}$ Pertama, Faktor internal menyangkut kepribadian dari pelaku kekerasan yang menyebabkan ia mudah sekali melakukan tindak kekerasan bila menghadapi situasi yang menimbulkan kemarahan atau frustasi. Kepribadian yang agresif biasanya dibentuk melalui interaksi dalam keluarga atau dengan lingkungan sosial di masa kanak-kanak. Tidaklah mengherankan bila kekerasan biasanya bersifat turun temurun, sebab anak-anak akan belajar tentang bagaimana akan berhadapan dengan lingkungan dari orang tuanya. Apalagi tindak kekerasan mewarnai kehidupan sebuah keluarga, kemungkinan besar anak-anak mereka akan mengalami hal yang sama setelah mereka menikah nanti. Hal ini disebabkan mereka menganggap bahwa kekerasan merupakan hal yang wajar atau mereka dianggap gagal kalau tidak mengulang pola kekerasa tersebut. Perasaan kesal dan marah terhadap orang tua yang selama ini berusaha ditahan, akhirnya akan muncul menjadi tindak kekerasan terhadap istri, suami atau anak-anak. Kedua, Faktor eksternal adalah faktor-faktor di luar diri si pelaku kekerasan. Mereka yang tidak tergolong memiliki tingkah laku agresif dapat melakukan tindak kekerasan bila berhadapan dengan situasi yang menimbulkan frustasi misalnya kesulitan ekonomi yang berkepanjangan (masalah keuangan), penyelewengan suami atau istri, masalah anak, masalah orang tua, masalah sopan santun dan sebagainya.

Faktor lingkungan lainnya seperti streotipe bahwa laki-laki adalah tokoh yang dominan, tegar dan agresif. Adapun perempuan harus bertindak pasif, lemah lembut dan mengalah. Dalam masyarakat, suami memiliki otoritas, memiliki pengaruh terhadap istri dan anggota keluarga yang lain, suami juga berperan sebagai pembuat keputusan.

\footnotetext{
${ }^{59}$ Moerti Hadiati Soeroso, Kekerasan dalam Rumah Tangga dalam Perspektif YuridisViktimologis, h. 76-77. Baca pula Sri Nurdjunaida, Sekilas Kekerasan Terhadap Perempuan (Jakarta: tp, 2008), 1.
} 
Pembedaan peran dan posisi antara suami istri dalam masyarakat diturunkan secara kultural pada setiap generasi bahkan diyakini sebagai ketentuan agama. Ini mengakibatkan suami ditempatkan sebagai orang yang memiliki kekuasaan yang lebih tinggi dari pada istri. Kekuasaan suami terhadap istri juga dipengaruhi oleh penguasaan suami dalam sistem ekonomi, sehingga masyarakat memandang pekerjaan suami lebih bernilai. Hal ini menyebabkan banyaknya kasus kekerasan yang dilakukan suami. Kebanyakan istri berusaha menyembunyikan masalah kekerasan dalam keluarganya karena merasa malu pada lingkungan sosial dan tidak ingin dianggap gagal dalam berumah tangga.

Selain hal tersebut di atas, adanya perubahan pada tingkat pendidikan dan jenis pekerjaan yang dimiliki oleh perempuan, khususnya di kota-kota besar juga menambah beban pada kaum lakilaki. Kini banyak perempuan yang bekerja di luar rumah dan memiliki penghasilan sendiri yang baik. Tidak jarang penghasilan mereka lebih besar dari pada penghasilan suami. Padahal secara normatif, laki-laki adalah kepala keluarga dan memiliki hak yang lebih daripada istri. Keadaan ini menimbulkan perasaan "tersaingi" dan tertekan pada kaum laki-laki yang dapat memunculkan tindak kekerasan dalam rumah tangga.

\section{Peran Dakwah Terhadap Tindak Kekerasan dalam Rumah Tangga}

Islam adalah agama risalah untuk manusia keseluruhannya. Umat Islam mendukung amanah untuk meneruskan risalah dengan dakwah, baik sebagai umat kepada umat-umat yang lain ataupun perseorangan di tempat manapun mereka berada menurut kemampuannya masingmasing. Dan di dalam hadis juga kita diperintahkan untuk menyampaikan walaupun hanya satu ayat.

Sebagai agama yang universal, Islam sangat memperhatikan keluarga. Hal ini sepadan dengan perhatiannya terhadap kehidupan individu serta kehidupan umat manusia secara keseluruhan. Keluarga adalah jiwa masyarakat dan tulang punggung kesejahteraan lahir bathin 
yang dinikmati oleh suatu bangsa. Sebaliknyanya, kebodohan dan keterbelakangannya adalah cermin dari keadaan keluarga-keluarga yang hidup pada masyarakat tersebut ${ }^{60}$ Oleh karena itu, Islam sangat menganjurkan pembinaan keluarga ideal yang oleh komunitas muslim Indonesia disebut dengan keluarga sakinah.

Kevarga sakinah adalah keluarga Islami dalam bentuk organisasi yang dibangun di atas pondasi nilai-nilai agama Islam. Menerapkan nilai-nilai tersebut dalam membangun keluarga, berarti menjadikannya sebagai keluarga teladan yang dapat menjadi panutan dan dambaan masyarakat. Dalam masyarakat tertentu, seseorang bisa dihormati dan dijadikan panutan karena keadaan rumah tangganya hidup rukun dan damai serta taat menjalankan ajaran agama Islam. Dalam hal ini menguatkan eksistensi keluarga sakinah sebagai wadah pesemaian mawaddah warahmah merupakan keniscayaan dalam wujud penguatan perannya. Hal ini diperkuat firman Allah dalam QS. Ar-Rum ayat 21:

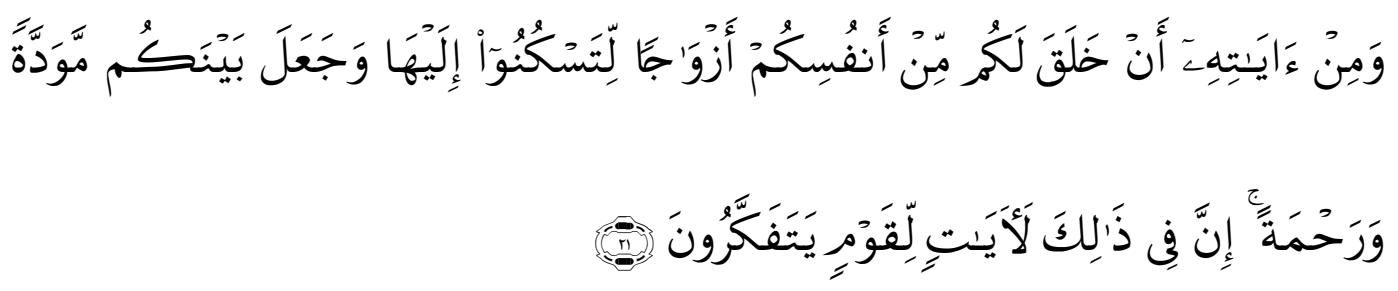

Terjemahan:

Dan di antara tanda-tanda kekuasaan-Nya ialah dia menciptakan untukmu isteri-isteri dari jenismu sendiri, supaya kamu cenderung dan merasa tenteram kepadanya, dan dijadikan-Nya diantaramu rasa kasih dan sayang. Sesungguhnya pada yang demikian itu benar-benar terdapat tanda-tanda bagi kaum yang berfikir. ${ }^{61}$

Dengan kata lain, ketika suami istri memiliki kasih sayang, perhatian dan cinta antara suami-istri dalam ikatan tali kasih nan suci, dengan saling mengisi dan melengkapi antara keduanya, akan mudah

${ }^{60}$ Lihat Quarish Shihab, Membumikan Al-Qura'an (Bandung: Mizan, 1994), 253.

${ }^{61}$ Departemen Agama Rl, Al-Quran dan Teriemahanya, (Semarang: Karya Toha Putra, 2002), 572. 
membentuk keluarga sakinah,dengan figur suami berakhlak karimah, bersanding dengan istri yang solehah.

Namun sayang, seiring dengan masuknya paham-paham materialism, pragmatism, dan hedonism ke dalam kehidupan rumah tangga, telah merubah arah rumah tangga, sehingga sederet kasus rumah tangga yang terungkap, semisal kasus kekerasan dalam rumah tangga, hal ini mencerminkan kehancuran moral yang berangkat dari kesenjangan keluarga.

Oleh sebab itu, Islam merupakan agama rahmatan lil alamin, yang ramah pada siapapun, melindungi, menyelamatkan dan memberikan penghargaan pada semua manusia tanpa kecuali, dari beragam suku, warna kulit, perbedaan kelas sosial ekonomi hingga perbedaan laki-laki dan perempuan. Salah satu misi Rasulullah saw. dalam menegakan Islam adalah mengangkat harakat dan martabat laki-laki maupun perempuan agar mendapatkan dan melindungi (bukan untuk dieksploitasi dan dianiaya) hak-hak pribadi sebagai manusia. Karena itu Islam melakukan perubahan tatanan hukum dan perundang-undangan yang diikuti pula dengan perubahan budaya yang tercermin dalam sikap dan praktik kehidupan Rasulullah melalui metode uswatun hasanahh. ${ }^{62}$

Dengan demikian jauh sebelumnya Rasulullah telah memprediksi bahwa problem relasi gender yang timpang akan terjadi sepanjang sejarah kehidupan manusia, untuk itu, beliau mengisyaratkan bahwa laki-laki memiliki potensi untuk melakukan kekerasan dan ketidakadilan terhadap perempuan. Di sisi lain Rasulullah mengisyaratkan bahwa perempuan berhak memperoleh perlindungan dan terbebas dari berbagai penindasan. Sebagaiman dalam hadis yang diriwayatkan alTurmudzi dikatakan bahwa:

"Ingatlah aku berpesan agar kalian berbuat baik terhadap perempuan karena mereka sering menjadi sasaran pelecehan di antara kalian, padahal sedikitpun kalian tidak berhak memperlakukan mereka, kecuali untuk kebaikan." ${ }^{163}$

\footnotetext{
${ }^{62}$ Mufidah, Psikologi Kelvarga Islam (Cet. I; Malang: UIN Malang Press, 2008), 278.

${ }^{63}$ Muhammad bin Isa Abu at-Turmudzi, Sunan Turmudzi (Juz 3; Beirut: Dar llya' Turats, H), 467.
} 
Kekerasan dalam rumah tangga sesungguhnya bukanlah teladan dari Rasulullah, pemahaman ini didasarkan pada fenomena praktek kenabian Muhammad saw. sebagai suri tauladan umat Islam. Rasulullah tidak pernah sekalipun mencontohkan memukul salah satu dari para istrinya. Tidak satupun riwayat dari para sahabat tentang fi'liyah (perbuatan) Nabi yang menceritakan hal tersebut. Bahkan dalam hadisnya Rasulullah saw. malah cenderung mengecam pemukulan terhadap istri tersebut. Seperti hadis dari Abu Hurairah, Rasulllah bersabda: janganlah seseorang di antara kamu memukul istrinya bagaikan unta, yaitu dia memukulnya pada pagi hari, tetapi kemudian pada malam harinya mencampurinya.

Ajaran Islam yang menjunjung martabat manusia tidak terkecuali perempuan sebagaiman dicontohkan dalam kehidupan Rasulullah tersebut, dalam realitas kehidupan umat Islam tidak selamanya sama dan sebangun, bahkan ada kecenderungan untuk bertentangan dengan ajaran Isam yang ideal. Hal ini disebabkan antara lain karena penafsiran terhadap teks suci yang melahirkan diskursus pemahaman yang tidak berkeadilan gender. Sebagaimana terdapat dalam QS. AnNisa (4): 34 .

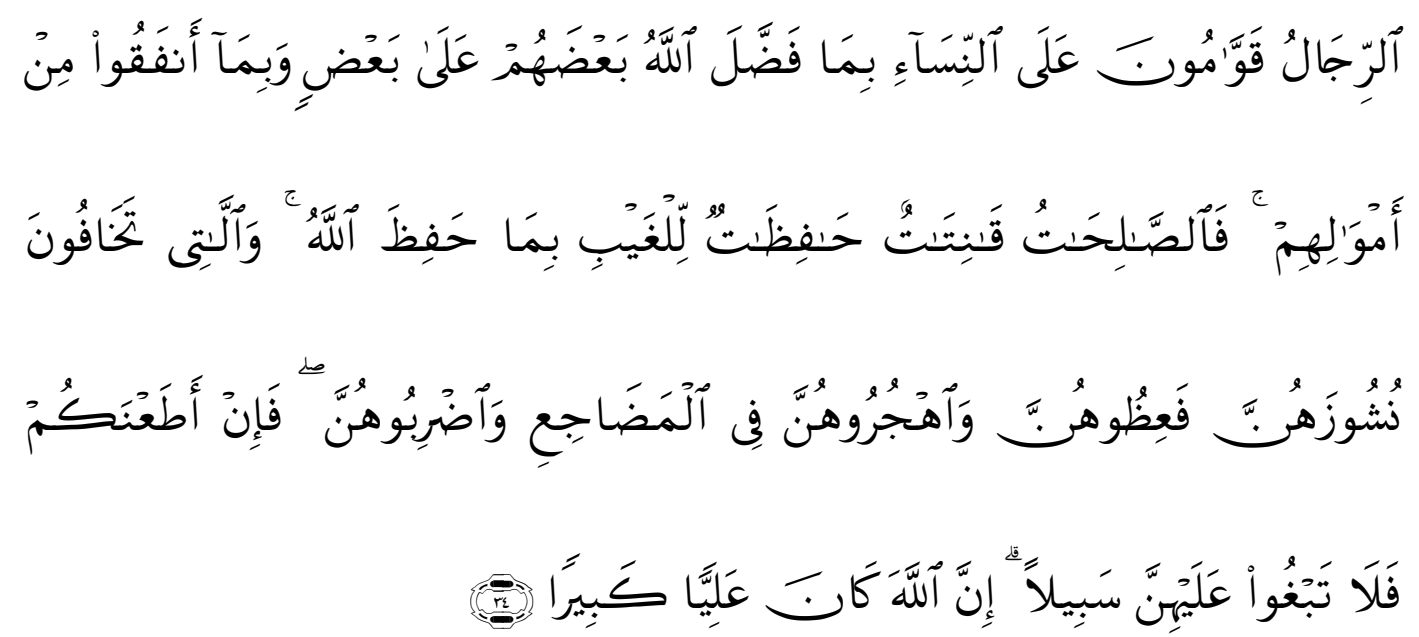

Terjemahan:

Kaum laki-laki itu adalah pemimpin bagi kaum wanita, oleh Karena Allah Telah melebihkan sebahagian mereka (laki-laki) atas 
sebahagian yang lain (wanita), dan Karena mereka (laki-laki) Telah menafkahkan sebagian dari harta mereka. sebab itu Maka wanita yang saleh, ialah yang taat kepada Allah lagi memelihara diri ketika suaminya tidak ada, oleh Karena Allah Telah memelihara (mereka). wanita-wanita yang kamu khawatirkan nusyuznya, Maka nasehatilah mereka dan pisahkanlah mereka di tempat tidur mereka, dan pukullah mereka. Kemudian jika mereka mentaatimu, Maka janganlah kamu mencari-cari jalan untuk menyusahkannya. Sesungguhnya Allah Maha Tinggi lagi Maha Besar. ${ }^{64}$

Kata qawwamun diartikan dengan laki-laki sebagai pemimpin dalam keluarga yang memiliki kekuasaan penuh atas istri. Penafsiran demikian ini menegaskan bahwa suami seolah-olah berhak secara mutlak menguasai istrinya dengan memperlakukan sewenang-wenang, dengan alasan mendidik, memperingati, meluruskan dan menyelamatkan. Demikian pula dengan kata nusyuz yang diartikan menentang, maka ketika seorang istri dipandang melakukan nusyuz, seorang suami bisa melakukan tiga tindakan: memberikan nasehat, memisahkan tempat tidur istri dan memukulnya. Istilah memukul dalam praktik kehidupan rumah tangga muslim seringkali dimaknai bahwa al-Quran membolehkan suami melakukan kekerasan fisik terhadap istrinya, meskipun dalam fiqih ada batasan-batasan tetapi dalam konteks masyarakat seperti Indonesia, memukul merupakan tindakan yang kurang sesuai dengan budaya bangsa.

Kebolehan memukul ini juga didasarkan pada hadis dari Ikrimah, bahwa rasulullah saw. bersabda: Pukullah mereka (istri) apabila menentangmu dalam kebaikan, dengan pukulan yang tidak meninggalkan bekas. Hadis tersebut juga dimaknai sebagai pukulan, diperkuat dengan kata pukulan yang tidak meninggalkan bekas. Sifat tidak meninggalkan bekas atau luka memang lebih tepat merupakan dampak dari suatu pukulan. Konsep memukul diletakkan dalam konteks solusi atas perilaku nusyuz istri. Posisinyapun terakhir setelah dua tahapan sebagaiman yang diposisikan al-Quran di atas.

${ }^{64}$ Departemen Agama RI, Al-Quran dan Terjemahannya, 108-109. 
Menurut Amina Wadud, Penggunaan kata memukul kurang signifikan jika dilihat dari berbagai aspek pendekatan penyelesaian masalah dalam rumah tangga. Dia menilai berbagai jalan perdamaian seperti: "...tidak ada dosa bagi keduanya jika mereka mengadakan perdamaian yang sebenarnya, perdamaian itu lebih baik. (QS. 4: 128). Perdamaian dengan proses berdialog secara ma'ruf merupakan solusi dalam mencari solusi atas konflik dalam rumah tangga. Hal inipun berlaku sangat khusus dalam konteks perkawinan dan bukan dalam wilayah perlakuan umum bagi setiap laki-laki kepada perempuan, misalnya kepada keluarga, tetangga maupun relasi sosial secara luas di masyarakat. ${ }^{65}$

Untuk meminimalisir kasus-kasus kekerasan dalam rumah tangga, sebagaimana diuraikan sebelumnya, maka di antara kegiatan dakwah yang dapat dilakukan oleh pelaku dakwah adalah: Pertama, menggalakan penyuluhan masyarakat berbasis dakwah. Kegiatan dakwah seperti ini dimaksudkan untuk memberikan pencerahan dan pemahaman kepada masyarakat, sehingga dapat membangun rumah tangga yang islami, yang kuat, dan terhindar dari berbagai sifat egoisme. Misalnya, menggalakkan pendidikan mengenai HAM dan pemberdayaan perempuan dengan menyebarkan informasi dan mempromosikan prinsip hidup sehat, mengadakan penyuluhan untuk mencegah kekerasan dalam rumah tangga, mensosialisasikan keseteraan gender karena banyak terjadi tindak kekerasan akibat masyarakat jarang mendapatkan pencerahan yang bersifat religius. Hal ini bisa dilakukan melalui majlis taklim atau pengajian-pengajian lainnya.

Kedva, membangun ekonomi masyarakat berbasis masjid. Terjadinya tindak kekerasan juga diakibatkan oleh perekonomian yang tidak baik. Oleh karena itu pelaku dakwah harus mengambil bagian dalam mengembangkan ekonomi umat melalui berbagai program masjid atau badan usaha masjid. Membangun badan usaha masjid

\footnotetext{
${ }^{65}$ Amina waded, Qur'an Menurut Perempuan, Membaca Kembali Kitab Suci dengan Semangat Keadilan, Alih bahasa. Abdullah Ali. (Jakarta: Serambi), 130.
} 
merupakan bagian dari usaha meningkatkan kemakmuran jamaah masjid, hal ini menjadi langkah yang sangat strategis untuk membangun perekonomian umat Islam, sehingga dapat mengurangi problem umat Islam yang lebih banyak berpusat pada masalah ekonomi.

Ketiga, memberdayakan etos kerja kaum muslim. Pelaku tindak kekerasan kebanyakan berasal dari kalangan yang tidak memiliki pekerjaan yang jelas sehingga waktu mereka banyak yang kosong, dan diisi dengan berbagai kegiatan yang tidak bermanfaat. Oleh karena itu sudah saatnya pelaku dakwah juga memikirkan bagaimana seseorang membagun kesuksesan, salah satu bentuknya dalah dengan membangun etos keria kaum muslim. Melalui kegiatan seperti ini diharapkan mereka dapat melihat peluang-peluang untuk mencapai kesuksesan.

Di samping itu, upaya-upaya lain yang bisa dilakukan baik oleh $d^{\prime}{ }^{\prime} i$, masyarakat, pemerintah maupun keluarga dalam meminimalisir kekerasan dalam rumah tangga antara lain adalah:

1. Tindakan Preventif, untuk mencegah terjadinya kekerasan dalam rumah tangga, perlu dilakukan sosialisasi/pembiasaan kepada anggota keluarga terintegrasi dengan penanaman nila-nilai agama dan budaya agar siapapun tidak melakukan kekerasan dan tidak pula menjadi korban kekerasan. Tindakan preventif ini dilakukan dengan contoh yang baik dari orang tua, saling mengingatkan jika ada indikasi kekerasan dalam rumah tangga.

2. Tindakan Edukatif, misalnya memberikan pendidikan anti kekerasan dan khususnya yang berbasis gender sejak dini untuk merubah persepsi terhadap kekerasan. Hal ini dilakukan melalui penerapan pendidikan kesetaraan gender baik di sekolah maupun dalam rumah tangga. Misalnya menyediakan sumber bacaan yang bersifat gender, pendidikan ramah anak dan ramah gender.

3. Tindakaan Kuratif, misalnya iika ada kasus kekerasan dalam rumah tangga, memberikan bantuan untuk memudahkan korban mendapatkan perlindungan, memberikan informasi yang diperlukan untuk memperoleh layanan pendampingan oleh pihak- 
piihak yang terkait. Membicarakan secara terbuka dalam keluarga lebih kondusif untuk pemulihan korban maupun penyadaran terhadap pelaku.

4. Tindakan Rehabilitatif, misalnya membaantu pemulihan mental, peguatan kepribadian dan mendorong tumbuhnya proses bersosialisasi dengan lingkungan pasca krisis. Bersikap wajar dan terbuka terhadap korban akan mempercepat proses rehabilitasi mental korban. ${ }^{66}$

Menurut hemat penulis, rumah tangga diibaratakan sebuah perahu yang berlayar di tengah lautan. Badai, ombak, dan gelombang besar bisa terjadi sewaktu-waktu, tergantung bagaimana tingkat kesiapan pasangan suami istri mampu mengendaalikan perahu agar sampai ke tujuan dengan selamat dan menyenangkan. Demikian pula rumah tangga pasti dihadapkan pada sejumlah masalah, namun penyelesaian masalah dapat diikhtiarkan tanpa menimbulkan kekerasan dalam rumah tangga.

\section{E. Kesimpulan}

KDRT adalah setiap perbuatan terhadap seseorang, terutama perempuan, yang berakibat timbulnya kesengsaraan atau penderiataan secara fisik, seksual, psikologis, dan atau penelantaran rumah tangga termasuk ancaman untuk melakukan perbuatan, pemaksaan, atau perampasan kemerdekaan secara melawan hukum dalam lingkup rumah tangga.

Adapan bentuk kekerasan dalam rumah tangga yakni kekerasan fisik, kekerasan seksual, kekerasan psikis dan kekerasan ekonomi. Secara umum penyebab terjadinya kekerasan dalam rumah tangga dapat digolongkan menjadi dua faktor, yaitu faktor internal dan eksternal. Faktor internal menyangkut kepribadian dari pelaku kekerasan yang menyebabkan ia mudah sekali melakukan tindak kekerasan bila menghadapi situasi yang menimbulkan kemarahan atau frustasi.

${ }^{66}$ Mufidah, Psikologi Keluarga Islam, 297-298. 
Faktor eksternal adalah faktor-faktor di luar diri si pelaku kekerasan. Misalnya kesulitan ekonomi yang berkepanjangan (masalah keuangan), penyelewengan suami atau istri, masalah anak, masalah orang tua, masalah sopan santun dan sebagainya. Untuk meminimalisir kasuskasus kekerasan dalam rumah tangga, maka pelaku dakwah menggalakan penyuluhan masyarakat berbasis dakwah, membangun ekonomi masyarakat berbasis masjid dan memberdayakan etos kerja kaum muslim. Hal ini bisa dilakukan melalui majlis taklim atau pengajian-pengajian lainnya. Upaya lain yang bisa dilakukan adalah tindakan preventif, edukatif, kuratif dan rehabilitatif. 


\section{Daftar Pustaka}

Departemen Agama R.I. Al-Qur'an dan Terjemahnya. Semarang: Karya Toha Putra, 1995.

Elmina Martha, Aroma, Hukum KDRT Kekerasan dalam Rumah Tangga. Yogyakarta: Aswaja Pressindo, 2015.

Freedman Lisa, Wife Assault, dalam Connie Guberman et al. (ed) Safe Place, Violence Againts Women and Children. Tronto, Ontario: Womens Press, 11985

Hadiati Soeroso, Moerti, Kekerasan dalam Rumah Tangga dalam Perspektif Yuridis-Viktimologis, Jakarta: Sinar Grafika, 2012

Morris Allison Women, Crime and Criminal Justice, USA: Basil Blackwell Inc, 1987

Mufidah, Psikologi Keluarga Islam, Cet. I; Malang: UIN Malang Press, 2008

Muhammad bin Isa Abu at-Turmudzi, Sunan Turmudzi, Juz 3; Beirut: Dar llya' Turats, H.

Nurdjunaida Sri, Sekilas Kekerasan Terhadap Perempuan, Jakarta: tp, 2008

UU RI Tentang Penghapusan Kekerasan dalam Rumah Tangga Nomor 23 Tahun 2004

Wadud Amina, Qur'an Menurut Perempuan, Mebaca Kembali Kitab Suci dengan Semangat Keadilan, Alih bahasa. Abdullah Ali. Jakarta: Serambi 